\title{
Spatial and temporal variability of rainfall erosivity factor for Switzerland
}

\author{
K. Meusburger ${ }^{1}$, A. Steel ${ }^{2}$, P. Panagos ${ }^{2}$, L. Montanarella ${ }^{2}$, and C. Alewell ${ }^{1}$ \\ ${ }^{1}$ Institute for Environmental Geosciences, University of Basel, Bernoullistrasse 30, 4056 Basel, Switzerland \\ ${ }^{2}$ Joint Research Centre of the European Commission, Institute for Environment and Sustainability, E. Fermi 2749, \\ 21027, Ispra (VA), Italy
}

Correspondence to: K. Meusburger (katrin.meusburger@unibas.ch)

Received: 17 August 2011 - Published in Hydrol. Earth Syst. Sci. Discuss.: 6 September 2011

Revised: 29 November 2011 - Accepted: 30 December 2011 - Published: 16 January 2012

\begin{abstract}
Rainfall erosivity, considering rainfall amount and intensity, is an important parameter for soil erosion risk assessment under future land use and climate change. Despite its importance, rainfall erosivity is usually implemented in models with a low spatial and temporal resolution. The purpose of this study is to assess the temporal- and spatial distribution of rainfall erosivity in form of the (Revised) Universal Soil Loss Equation $R$-factor for Switzerland. Time series of $22 \mathrm{yr}$ for rainfall (10 min resolution) and temperature $(1 \mathrm{~h}$ resolution) data were analysed for 71 automatic gauging stations distributed throughout Switzerland. Regression-kriging was used to interpolate the rainfall erosivity values of single stations and to generate a map for Switzerland. Latitude, longitude, average annual precipitation, biogeographic units (Jura, Midland, etc.), aspect and elevation were used as covariates, of which average annual precipitation, elevation and the biographic unit (Western Central Alps) were significant $(p<0.01)$ predictors. The mean value of long-term rainfall erosivity is $1330 \mathrm{MJ} \mathrm{mm} \mathrm{ha}^{-1} \mathrm{~h}^{-1} \mathrm{yr}^{-1}$ with a range of lowest values of $124 \mathrm{MJ} \mathrm{mm} \mathrm{ha}{ }^{-1} \mathrm{~h}^{-1} \mathrm{yr}^{-1}$ at an elevated station in Grisons to highest values of $5611 \mathrm{MJ} \mathrm{mm} \mathrm{ha}^{-1} \mathrm{~h}^{-1} \mathrm{yr}^{-1}$ in Ticino. All stations have highest erosivity values from July to August and lowest values in the winter months. Swisswide the month May to October show significantly increasing trends of rainfall erosivity for the observed period ( $p<$ 0.005). Only in February a significantly decreasing trend of rainfall erosivity is found $(p<0.01)$. The increasing trends of rainfall erosivity in May, September and October when vegetation cover is scarce are likely to enhance soil erosion risk for certain agricultural crops and alpine grasslands in Switzerland.
\end{abstract}

\section{Introduction}

Soil erosion by water in Switzerland is a major environmental threat because Switzerland is one of the countries where strongest effects of climate change are expected (Beniston, 2006; IPCC, 2007). In addition, profound land use changes occur predominantly in the susceptible mountainous areas (Tasser and Tappeiner, 2002; Mottet et al., 2006; Meusburger and Alewell, 2008). Rainfall is one of the main drivers of soil erosion by water. Climate change may lead to changes in rainfall characteristics and is thus a major concern to soil conservation. The relation between rainfall and sediment yield is given by the rainfall erosivity, which quantifies the kinetic energy of raindrop impact and rate of associated surface runoff. As field measurements of the kinetic energy of rainfall are scarce both in space and time, numerous works have assessed the relationship between conventional rainfall characteristics and soil detachment e.g. Hudson (1971) for the USA and some regions in Africa, Lal (1976) for Nigeria and Arnoldus (1977) for Morocco. The most prominent and widely-used for temperate zones is probably the (Revised) Universal Soil Loss Equation $R$-factor, which is the sum of all erosive events during a one year period (Wischmeier and Smith, 1978; Brown and Foster, 1987; Renard et al., 1997).

Few torrential rainfall events are often responsible for large sediment yields, these events cannot be identified from rainfall data with low temporal resolution (Renard et al., 1997). In the context of varying soil erosion susceptibility caused by seasonal changes in the protective vegetation cover (Panagos et al., 2011), the temporal distribution throughout the year and the timing of the most severe events is an important characteristic of rainfall erosivity. In many studies the 
rainfall erosivity calculation is limited to either time-series analysis of single stations (Mikos et al., 2006; Verstraeten et al., 2006) or for larger spatial scales to regional approximation equations (Bollinne et al., 1979; Rogler and Schwertmann, 1981; Renard and Freimund, 1994; Strauss and Blum, 1994; De Santos Loureiro and De Azevedo Coutinho, 2001; Diodato and Bellocchi, 2007, 2010; Capolongo et al., 2008). The original method to calculate the erosivity values for a storm event requires pluviographic records (Wischmeier, 1978). Due to limited availability of long precipitation time-series with a high temporal resolution, several alternative strategies have been deployed based on the rainfall volume (instead of intensity) for $R$-factor estimation. However, authors of those erosivity equations suggest using them with caution especially for the alpine region (Mikos et al., 2006). Only few studies exist that determine $R$-factor directly from high temporal resolution data in mountain areas of Europe (Rogler and Schwertmann, 1981; Strauss and Blum, 1994; Loureiro and Coutinho, 2001; Mikos et al., 2006; Angulo-Martinez et al., 2009). For Switzerland the rainfall erosivity map is so far based on a combined approximation equation proposed by Friedli et al. (2006), where long-term $R$-factor is approximated by average annual precipitation (mm) after Rogler and Schwertmann (1981) and proportion of snowfall is approximated by elevation ( $\mathrm{m}$ a.s.l.) after Schüpp (1975). Because rainfall erosivity is not distributed uniformly through the year, for the evaluation of soil erosion hazard continuous maps and temporal patterns of rainfall erosivity are needed. Interpolation of rainfall erosivity is challenging because of the high temporal and spatial variability of the $R$-factor long time series and good covariates are needed.

This study aims to evaluate the temporal as well as the spatial distribution of rainfall erosivity and to produce a map of average annual rainfall erosivity for Switzerland. We propose an automated algorithm for estimation of rainfall erosivity $R$-factor from high resolution precipitation- and temperature data. Including an adaptation of the code to account for snowfall in elevated areas of Switzerland.

\section{Materials and methods}

The precipitation regime of Switzerland is characterised by a distinct seasonality with lowest precipitation in winter and highest in summer. The rainfall distribution in winter is characterised by westerly winds causing high precipitation in the north-western part and low precipitation in central and eastern parts of Switzerland. The relief of the Alps has a strong influence on precipitation and temperature. Convection events promoted by the mountainous relief are an important driver of total rainfall in summer. The south side of the Alps is characterised by high rainfall exceeding the national average for all seasons except for the relatively dry winters. Rainfall data was available for 71 automatic and

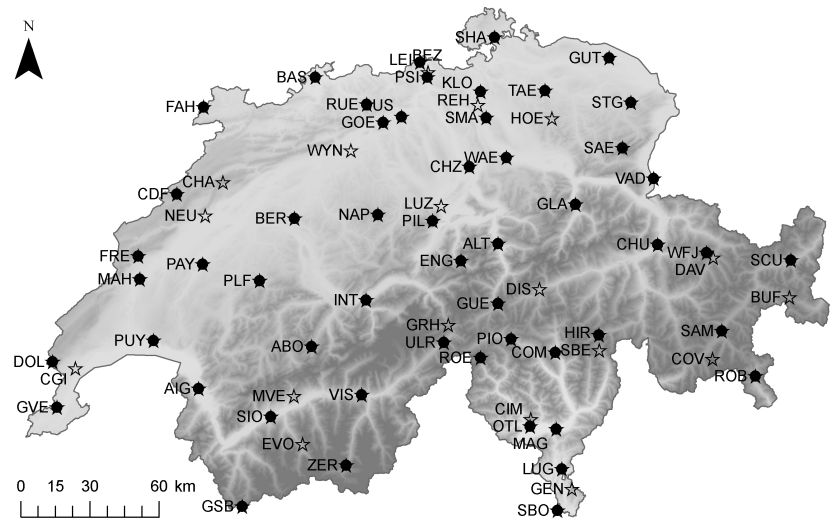

Fig. 1. Location of automatic rainfall stations in Switzerland (star dots are stations used for the validation of the rainfall erosivity map).

heated stations in Switzerland (Fig. 1). Each station provides precipitation data at a time resolution of $10 \mathrm{~min}$ and temperature data at a time resolution of $1 \mathrm{~h}$. For most of the stations $(n=56)$ time series of $22 \mathrm{yr}$ were available. The remaining stations had a recording length of at least $5.4 \mathrm{yr}$. The data were subject to a quality control by MeteoSchweiz (Begert et al., 2005). The stations are well distributed throughout Switzerland (Fig. 1) and represent different geographical zones and climate regions.

\subsection{Computation of rainfall erosivity}

The RUSLE $R$-factor was employed to create a database of erosive events. RUSLE $R$-factor is the product of kinetic energy of a rainfall event and its maximum 30-min intensity (Brown and Foster, 1987):

$R=\frac{1}{n} \sum_{j=1}^{n} \sum_{k=1}^{m_{j}}\left(E I_{30}\right)_{k}$

where $R$-factor is average annual rainfall erosivity $\left(\mathrm{MJ} \mathrm{mm} \mathrm{ha} \mathrm{m}^{-1} \mathrm{~h}^{-1} \mathrm{yr}^{-1}\right), \quad n$ is the number of years of records, $m_{j}$ is the number of erosive events of a given year $j$, and $\mathrm{EI}_{30}$ is the rainfall erosivity index of a single event $k$. The event erosivity $\mathrm{EI}_{30}\left(\mathrm{MJ} \mathrm{mm} \mathrm{ha}^{-1} \mathrm{~h}^{-1}\right)$ is defined as:

$\mathrm{EI}=\mathrm{EI}_{30}=\left(\sum_{r=1}^{0} e_{r} v_{r}\right) I_{30}$

where $e_{\mathrm{r}}$ is the unit rainfall energy $\left(\mathrm{MJ} \mathrm{ha}^{-1} \mathrm{~mm}^{-1}\right)$ and the $v \mathrm{r}$ the rainfall volume $(\mathrm{mm})$ during a time period $r . I_{30}$ is the maximum rainfall intensity during a period of $30 \mathrm{~min}$ in the event $\left(\mathrm{mm} \mathrm{h}^{-1}\right)$. The unit rainfall energy is calculated for each time interval as follows:

$e_{\mathrm{r}}=0.29\left[1-0.72 \exp \left(-0.05 i_{\mathrm{r}}\right)\right]$ 

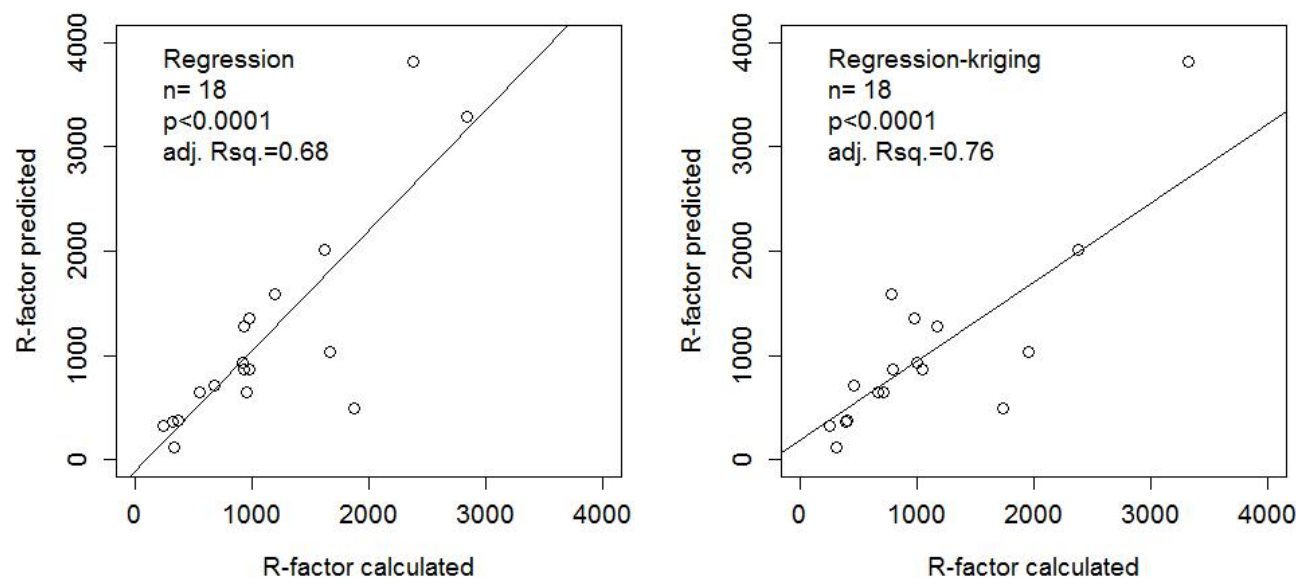

Fig. 2. Scatterplot between calculated and predicted $R$-factor values for the validation dataset: after the multiple regression (left) and after the regression-kriging (right).

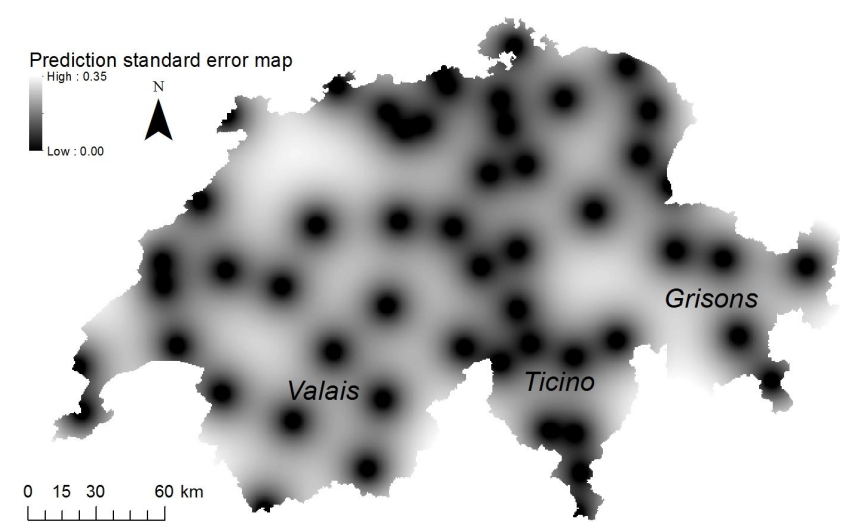

Fig. 3. The prediction standard error map for the kriging of the residuals resulting from the multiple regression.

where $i_{\mathrm{r}}$ is the rainfall intensity during the time interval $\left(\mathrm{mm} \mathrm{h}^{-1}\right)$. In addition to the $R$-factor we calculated monthly sums of $\mathrm{EI}_{30}$.

The criteria for the identification of an erosive event are given by Renard et al. (1997): (i) the cumulative rainfall of an event should be greater than $12.7 \mathrm{~mm}$, or (ii) the event has at least one peak that is greater than $6.35 \mathrm{~mm}$ in $15 \mathrm{~min}$ and (iii) a rainfall-period of less than $1.27 \mathrm{~mm}$ in $6 \mathrm{~h}$ is used to divide a longer storm period into two storms.

In our code we modified the second criteria of Renard et al. (1997). A threshold of $8.47 \mathrm{~mm} / 20 \mathrm{~min}$ instead of $6.35 \mathrm{~mm} / 15 \mathrm{~min}$ was used in order to best fit to the time resolution of the precipitation data $(10 \mathrm{~min})$. The likelihood to observe an $8.47 \mathrm{~mm} / 20 \mathrm{~min}$ event is slightly smaller than a $6.35 \mathrm{~mm} / 15 \mathrm{~min}$ event. However, the additional number of erosive events due to this intensity criteria is marginal (only two stations had additional events due to the changed intensity criteria). Several stations are elevated and a large proportion of the annual precipitation occurs as snowfall that

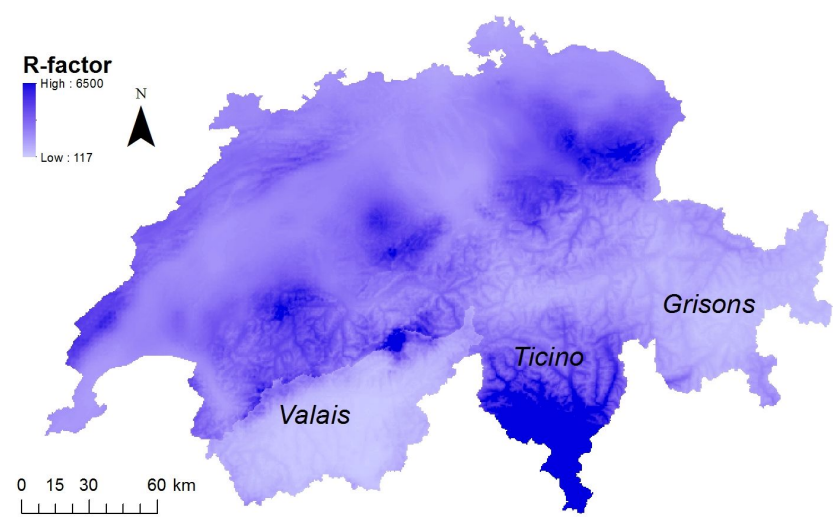

Fig. 4. (R)USLE $R$-factor map (MJ mm ha ${ }^{-1} \mathrm{~h}^{-1} \mathrm{yr}^{-1}$ ) of Switzerland resulting from regression-kriging interpolation of 71 stations.

the heated stations measure erroneously as rainfall. For this reason a temperature threshold, below which precipitation records are not considered when searching for rainfall events, was used. Here we applied a temperature threshold of $0^{\circ} \mathrm{C}$ (Leek and Olsen, 2000).

The algorithm was implemented in $\mathrm{C}$ programming language. The proposed algorithm can be reused for other local/regional/national applications where rainfall data and temperature data are available with the same temporal resolution.

\subsection{Rainfall erosivity mapping for Switzerland}

The dataset consists of 71 stations for an area of $41285 \mathrm{~km}^{2}$. Regression-kriging was used to interpolate the at-site estimated $R$-factor to a map. The purpose of the multiple regression was to identify relations between the target variable (here: $R$-factor) and other variables with a better spatial resolution (covariates). The resulting residual map was 
Table 1. Average annual $R$-factor (MJ mm ha ${ }^{-1} \mathrm{~h}^{-1} \mathrm{yr}^{-1}$ ) of the (Revised) Universal Soil Loss Equation and descriptive statistics of the event's rainfall erosivity $\left(\mathrm{MJ} \mathrm{mm} \mathrm{ha}^{-1} \mathrm{~h}^{-1}\right)$ for single stations.

\begin{tabular}{|c|c|c|c|c|c|c|c|}
\hline station & acronym & $R$-factor & $\begin{array}{r}\text { length of } \\
\text { time series (year) }\end{array}$ & $\begin{array}{l}\text { missing } \\
\text { data }(\%)\end{array}$ & $\begin{array}{r}\text { mean } \\
\mathrm{EI}_{30}\end{array}$ & $\begin{array}{r}\text { stdev. } \\
\mathrm{EI}_{30}\end{array}$ & $\begin{array}{l}\max . \\
\mathrm{EI}_{30}\end{array}$ \\
\hline Adelboden & $\mathrm{ABO}$ & 2143.0 & 22.0 & 0.3 & 39.0 & 75.6 & 710.5 \\
\hline Aigle & AIG & 758.4 & 22.0 & 0.2 & 32.8 & 67.1 & 1162.8 \\
\hline Altdorf & ALT & 921.2 & 22.0 & 0.1 & 35.7 & 98.2 & 1500.7 \\
\hline Basel/Binningen & BAS & 853.3 & 22.0 & 0.9 & 57.0 & 119.1 & 1101.9 \\
\hline Bern/Zollikofen & BER & 1052.0 & 22.0 & 0.8 & 47.6 & 79.7 & 698.3 \\
\hline Beznau & $\mathrm{BEZ}$ & 648.3 & 22.0 & 0.4 & 31.2 & 69.4 & 966.8 \\
\hline Buffalora & BUF & 370.4 & 11.8 & 0.6 & 30.0 & 41.4 & 339.6 \\
\hline Buchs/Aarau & BUS & 937.4 & 22.0 & 0.3 & 45.0 & 76.4 & 675.8 \\
\hline La Chaux-de-Fonds & $\mathrm{CDF}$ & 1445.2 & 22.0 & 0.4 & 46.4 & 143.2 & 3072.8 \\
\hline Nyon/Changins & CGI & 863.4 & 22.0 & 0.9 & 38.1 & 90.0 & 1114.3 \\
\hline Chasseral & $\mathrm{CHA}$ & 865.9 & 22.0 & 0.1 & 49.5 & 81.3 & 697.4 \\
\hline Chur & $\mathrm{CHU}$ & 578.0 & 22.0 & 0.1 & 34.6 & 72.6 & 1074.8 \\
\hline Cham & $\mathrm{CHZ}$ & 746.4 & 17.4 & 0.6 & 43.9 & 69.2 & 671.1 \\
\hline Cimetta & CIM & 3810.6 & 22.0 & 1.3 & 150.5 & 291.7 & 2517.2 \\
\hline Acquarossa/Comprovasco & $\mathrm{COM}$ & 1727.1 & 22.0 & 0.9 & 73.5 & 164.9 & 2763.6 \\
\hline Piz Corvatsch & $\mathrm{COV}$ & 123.9 & 22.0 & 1.2 & 30.0 & 25.1 & 132.5 \\
\hline Davos & DAV & 644.8 & 22.0 & 0.1 & 34.8 & 48.4 & 621.0 \\
\hline Disentis/Sedrun & DIS & 714.2 & 22.0 & 0.4 & 40.8 & 62.4 & 518.0 \\
\hline La Dôle & DOL & 1652.0 & 22.0 & 0.3 & 51.8 & 76.9 & 694.9 \\
\hline Engelberg & ENG & 1162.2 & 22.0 & 0.3 & 35.6 & 48.4 & 461.0 \\
\hline Evolène/Villa & EVO & 319.3 & 22.0 & 1.0 & 31.6 & 99.0 & 1392.1 \\
\hline Fahy & FAH & 918.7 & 22.0 & 0.1 & 42.2 & 78.9 & 742.4 \\
\hline Bullet/La Fraz & FRE & 1314.4 & 22.0 & 1.3 & 48.2 & 124.4 & 1962.3 \\
\hline Monte Generoso & GEN & 3282.5 & 15.0 & 5.0 & 153.9 & 305.5 & 2761.1 \\
\hline Glarus & GLA & 1272.7 & 22.0 & 0.3 & 36.2 & 66.3 & 1237.4 \\
\hline Goesgen & GOE & 822.3 & 22.0 & 0.3 & 39.0 & 74.0 & 658.7 \\
\hline Grimsel Hospiz & GRH & 495.3 & 21.5 & 0.9 & 30.1 & 59.8 & 741.6 \\
\hline Col du Grand St-Bernard & GSB & 965.9 & 22.0 & 0.3 & 59.1 & 117.5 & 1474.1 \\
\hline Guetsch ob Andermatt & GUE & 521.4 & 22.0 & 0.4 & 45.8 & 67.8 & 442.8 \\
\hline Guettingen & GUT & 864.2 & 22.0 & 0.8 & 45.5 & 87.2 & 825.9 \\
\hline Genève-Cointrin & GVE & 812.7 & 22.0 & 0.4 & 37.7 & 60.5 & 691.3 \\
\hline Hinterrhein & HIR & 1956.8 & 20.1 & 0.3 & 77.8 & 122.8 & 1035.8 \\
\hline Hoernli & HOE & 1035.2 & 5.4 & 0.6 & 37.6 & 63.9 & 547.2 \\
\hline Interlaken & INT & 1034.6 & 22.0 & 0.4 & 38.3 & 68.2 & 866.7 \\
\hline Zuerich/Kloten & KLO & 1291.0 & 6.8 & 0.0 & 53.8 & 99.3 & 789.1 \\
\hline Leibstadt & LEI & 619.4 & 22.0 & 0.2 & 29.0 & 50.5 & 504.6 \\
\hline Lugano & LUG & 4672.7 & 22.0 & 0.1 & 138.2 & 306.3 & 4625.9 \\
\hline Luzern & LUZ & 1592.6 & 22.0 & 0.4 & 58.6 & 107.6 & 1412.7 \\
\hline Magadino/Cadenazzo & MAG & 5032.5 & 22.0 & 0.3 & 160.9 & 313.8 & 3657.1 \\
\hline Mathod & MAH & 1021.9 & 18.3 & 1.3 & 82.9 & 250.0 & 2440.0 \\
\hline Montana & MVE & 362.18 & 22.0 & 0.1 & 23.6 & 26.9 & 251.2 \\
\hline Napf & NAP & 1878.4 & 22.0 & 1.1 & 60.2 & 114.6 & 1176.6 \\
\hline Neuchael & $\mathrm{NEU}$ & 932.8 & 22.0 & 0.3 & 46.3 & 114.1 & 1528.4 \\
\hline Locarno Monti & OTL & 5611.0 & 22.0 & 0.8 & 178.0 & 445.0 & 5603.9 \\
\hline Payerne & PAY & 834.5 & 22.0 & 0.1 & 47.6 & 133.9 & 2069.3 \\
\hline Pilatus & PIL & 1054.2 & 22.0 & 0.3 & 61.2 & 122.0 & 1400.5 \\
\hline Piotta & $\mathrm{PIO}$ & 1694.5 & 22.0 & 0.0 & 70.8 & 115.0 & 884.5 \\
\hline Plaffeien & PLF & 1571.3 & 21.1 & 0.7 & 57.0 & 98.4 & 997.2 \\
\hline PSI Wuerenlingen & PSI & 677.5 & 18.8 & 0.0 & 30.9 & 56.2 & 771.2 \\
\hline Pully & PUY & 1192.7 & 22.0 & 0.3 & 47.1 & 83.5 & 741.3 \\
\hline Zuerich/Affoltern & $\mathrm{REH}$ & 1283.6 & 6.8 & 0.0 & 54.9 & 140.7 & 1609.4 \\
\hline Poschiavo/Robbia & ROB & 913.0 & 22.0 & 0.1 & 41.2 & 74.9 & 821.0 \\
\hline
\end{tabular}


Table 1. Continued.

\begin{tabular}{|c|c|c|c|c|c|c|c|}
\hline station & acronym & $R$-factor & $\begin{array}{r}\text { length of } \\
\text { time series (year) }\end{array}$ & $\begin{array}{r}\text { missing } \\
\text { data }(\%)\end{array}$ & $\begin{array}{r}\text { mean } \\
\mathrm{EI}_{30}\end{array}$ & $\begin{array}{r}\text { stdev. } \\
\mathrm{EI}_{30}\end{array}$ & $\begin{array}{l}\max . \\
\mathrm{EI}_{30}\end{array}$ \\
\hline Robièi & ROE & 2721.4 & 19.9 & 1.5 & 93.7 & 159.6 & 1596.2 \\
\hline Ruenenberg & RUE & 917.7 & 22.0 & 0.3 & 46.6 & 97.4 & 1146.5 \\
\hline Saetis & SAE & 2362.9 & 22.0 & 0.6 & 99.2 & 309.4 & 5484.1 \\
\hline Samedan & SAM & 339.9 & 22.0 & 0.1 & 25.7 & 32.6 & 381.7 \\
\hline S. Bernardino & SBE & 2008.7 & 22.0 & 1.0 & 71.0 & 110.1 & 1029.3 \\
\hline Stabio & SBO & 4708.1 & 22.0 & 0.3 & 153.2 & 347.6 & 5686.3 \\
\hline Scuol & SCU & 489.9 & 22.0 & 0.2 & 36.6 & 97.6 & 1274.1 \\
\hline Schaffhausen & SHA & 744.0 & 22.0 & 0.7 & 41.8 & 95.0 & 1254.3 \\
\hline Sion & $\mathrm{SIO}$ & 278.5 & 22.0 & 0.4 & 22.5 & 28.3 & 225.8 \\
\hline Zuerich/Fluntern & SMA & 1090.5 & 22.0 & 0.8 & 45.8 & 83.7 & 781.9 \\
\hline St. Gallen & STG & 1499.4 & 22.0 & 0.3 & 55.0 & 106.2 & 1555.1 \\
\hline Aadorf/Taenikon & TAE & 1374.2 & 22.0 & 0.9 & 49.4 & 100.6 & 1184.9 \\
\hline Ulrichen & ULR & 642.9 & 22.0 & 0.3 & 32.8 & 46.8 & 388.4 \\
\hline Vaduz & VAD & 810.0 & 22.0 & 0.1 & 41.9 & 112.1 & 1498.5 \\
\hline Visp & VIS & 223.3 & 22.0 & 0.4 & 22.4 & 33.3 & 245.6 \\
\hline Waedenswil & WAE & 1658.2 & 22.0 & 0.9 & 50.7 & 122.6 & 2589.0 \\
\hline Weissfluhjoch & WFJ & 654.5 & 6.8 & 0.0 & 43.4 & 60.8 & 552.5 \\
\hline Wynau & WYN & 1350.6 & 6.8 & 0.0 & 55.0 & 103.4 & 779.4 \\
\hline Zermatt & ZER & 207.4 & 6.8 & 0.0 & 25.5 & 27.5 & 172.7 \\
\hline
\end{tabular}

interpolated by ordinary kriging and added to the regression map in order to improve the spatial prediction. Regressionbased methods have proved to be suitable for large regions with complex atmospheric conditions and with sparse sample network (Daly et al., 2002; Weisse and Bois, 2002). Kriging might further improve the spatial prediction if there is a spatial dependence of the regression residuals (Hengl et al., 2004). The elevation, aspect (digital elevation model of Swisstopo, $25 \mathrm{~m}$ spatial resolution), latitude, longitude, average (1971-1990) annual precipitation map on a grid of 1.25 min mesh width (Schwarb, 2000), and the main biogeographic units of Switzerland (Gonseth et al., 2001) were used as covariates. The biogeographic unit map is the only categorical variable (6 categories: namely Jura, Midland, north side of the Alps, south side of the Alps, Western and Eastern Alps) and was transformed to indicator maps.

For the multiple regression analysis the variance inflation factor (vif) was used to assess multicollinearity between the covariates. Further the covariates were normalised by subtracting the mean from the raw data and then dividing by the standard deviation (standard score procedure). The $R$ factor was log-transformed to achieve a normal distribution. The "best" subset of predictors was selected by a stepwise forward selection procedure. The significance for inclusion of a predictor was set to 0.05 for exclusion to 0.1 . The regression coefficients were determined by generalised least squares estimation that allows for spatial correlation of residuals (Cressie, 1993) and were used to derive the regression map in Esri ArcGIS 10. A stable semivariogram model was used to parameterise the spatial autocorrelation between the residuals coming from the regression multiple analysis. Nonconstant error variance test was used to assess homoscedasticity of the residuals of the regression-kriging. Prior to the regression-kriging procedure a stratified split into an interpolation (53 stations) and a validations dataset (18 stations) was done. The validation data was selected in such a way to both represent the entire study area and to decluster the dataset (Fig. 1).

The multiple regression was done with $\mathrm{R}$ statistical analysis package ( $\mathrm{R}$ Development Core Team, v 2.13), the geostatistical analyses were done in Esri ArcGIS 10.

\subsection{Trend analysis}

A minimum time period of $20-25 \mathrm{yr}$ is recommended for the calculation of a long-term $R$-factor (Wischmeier, 1987; Renard, 1997). However, these time series might not be long enough for trend analysis due to the high temporal variability of rainfall erosivity. Five tests were selected to evaluate the departure of homogeneity in the $R$-factor time series at stations with data for $22 \mathrm{yr}$ : the standard normal homogeneity test (SNHT) (Alexandersson, 1986), the Buishand range test (Buishand, 1982), the Pettitt test (Pettitt, 1979), the Neumann ratio test (Von Neumann, 1942) and the seasonal Mann-Kendall test (Hirsch et al., 1982). The first three tests are more suitable to identify break points in timeseries data. The Pettit test is based on ranks, which implies that it is less sensitive to outliers. The Buishand range and SNHT test assume a normal distribution of the test variable. The Neumann-ratio and the Seasonal Mann-Kendall test are 

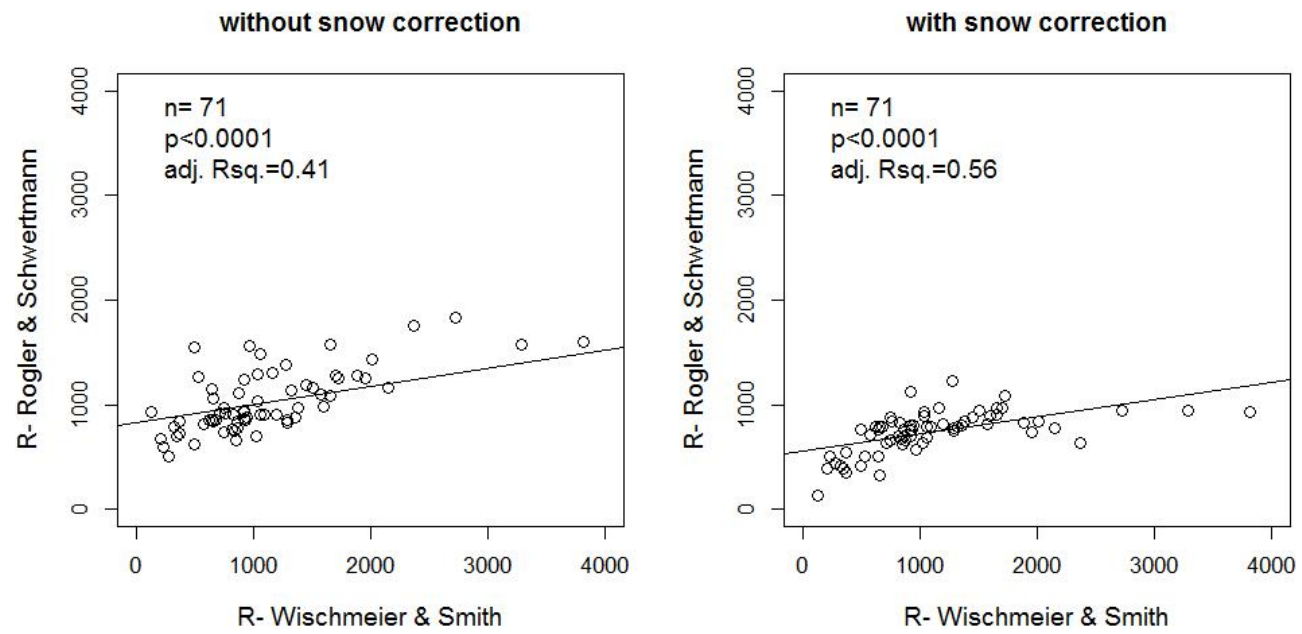

Fig. 5. Comparison or $R$-factor calculated from $10 \mathrm{~min}$ data versus $R$-factor based on average annual rainfall using the (left) approximation equation of Rogler and Schwertmann (1981) and (right) the adapted one by Friedli et al. (2006).

capable to identify monotonic trends of a time-series. The Seasonal Mann-Kendall test was applied for the monthly erosivity values. Yearly $R$-factor values were tested with the four other tests. Additionally a Mann-Kendall trend test was used to identify trends for individual month of all stations (Mann, 1945). The seasonal variability of rainfall erosivity is illustrated by monthly regime coefficients, which is the erosion index $\left(\mathrm{EI}_{30}\right)$ summarised over a specific month (January, February, ..., December) for all years divided by the erosion index summarised over the entire period. The regime coefficient is a normalised value, which allows for relative comparison between of seasonal dynamic between stations.

\section{Results and discussion}

\subsection{Rainfall erosivity map of Switzerland}

The long-term $R$-factor is significantly ( $p<0.001$ ) related to average annual precipitation and could explain $53.4 \%$ of the spatial variation. Elevation is another significant $(p<0.001)$ predictor that further improved the prediction $(74.1 \%$ of the observed variability could be explained with these two predictors alone). The indicator map of the Western Central Alps (Canton Valais) was another significant $(p<0.01)$ predictor. Covariates as latitude, longitude, aspect and the other biogeographic units were excluded by stepwise multiple regression. The following multiple regression equation was used to interpolate the long-term $R$-factor of the single stations:

$\log R=0.549 \mathrm{nP}-0.358$ ndem -0.586 west +6.996

where $\mathrm{nP}$ is the normalized average annual precipitation, ndem the normalized elevation and west the biogeographic unit indicator map of the Western Central Alps. The multiple regression model based on three predictors could explain
$79.5 \%$ of the observed spatial variability of the interpolation dataset and yielded also a good prediction $\left(R^{2}=0.68\right)$ for the independent validation dataset (Fig. 2 left). The residuals of the model are normally distributed and a non-constant error variance test confirmed homoscedasticity of the residuals $(p=0.015)$. The vif indicated a collinearity between average annual precipitation and elevation (vif $<3.3$ ). However, regression models based on either annual precipitation or elevation yielded lower $R^{2}$ values and heteroscedasticity of the residuals.

The residuals derived from the multiple regression analysis were interpolated by ordinary kriging using a stable semivariogram model. The semivariogram of the residuals showed a clear spatial dependence with a range parameter of $56 \mathrm{~km}$. The prediction standard error map shows lowest prediction errors close to the interpolation points. The prediction error gradually increases with distance to the interpolation points (Fig. 3). The estimates of the regression model and the krigged residuals were added to produce a regression-kriging prediction. The predictions of the regression-kriging for the independent validation dataset performed better $\left(R^{2}=0.76\right)$ than for the multiple regression model alone (Fig. 2 right). Further, the residuals resulting from the regression-kriging prediction were normally distributed and homoscedastic (non-constant error variance test: $p=0.527$ ).

Several techniques for mapping the rainfall erosivity have been compared by Angulo-Martinez et al. (2009) for a study site in Spain (Ebro basin $85000 \mathrm{~km}^{2}$ ) using precipitation data of 112 stations. Concerning the validation statistics local interpolation methods like Inverse Distance Weighting (IDW) performed best for the Ebro basin. Compared to spline- and kriging interpolation IDW performed also best for a study area in Japan (Santosa et al., 2010). One explanation might be the lack of significant relations between rainfall erosivity 
Table 2. Mann-Kendall trend test of $R$-factor using the monthly dataset of of all Swiss stations. Tau is the Mann-Kendall rank correlation coefficient.

\begin{tabular}{lrr}
\hline month & tau & 2-sided \\
-value \\
\hline January & 0.015 & 0.453 \\
February & -0.052 & 0.006 \\
March & 0.033 & 0.045 \\
April & 0.030 & 0.041 \\
May & 0.047 & 0.000 \\
June & 0.032 & 0.003 \\
July & 0.040 & 0.000 \\
August & 0.038 & 0.001 \\
September & 0.055 & 0.000 \\
October & 0.040 & 0.001 \\
November & 0.018 & 0.211 \\
December & -0.001 & 0.493 \\
\hline
\end{tabular}

and the spatial covariates. For the Swiss dataset the predictive power of the covariates is good, thus, the regressionkriging interpolation seemed to be the best choice for the Swiss rainfall erosivity map (Fig. 4).

The mean $R$-factor of all investigated stations is $1330 \mathrm{MJ} \mathrm{mm} \mathrm{ha}^{-1} \mathrm{~h}^{-1} \mathrm{yr}^{-1}$ with a maximum of $5611 \mathrm{MJ} \mathrm{mm} \mathrm{ha}^{-1} \mathrm{~h}^{-1} \mathrm{yr}^{-1}$ at the station Locarno Monti in Ticino (south side of the Alps) and a minimum of $124 \mathrm{MJ} \mathrm{mm} \mathrm{ha}^{-1} \mathrm{~h}^{-1} \mathrm{yr}^{-1}$ at the station Corvatsch in Grisons (Eastern Central Alps). The descriptive statistic of the obtained Swiss $R$-factor map shows similar characteristics with a mean $R$-factor of $1217 \mathrm{MJ} \mathrm{mm} \mathrm{ha}^{-1} \mathrm{~h}^{-1} \mathrm{yr}^{-1}$ that ranges from 117 to $6500 \mathrm{MJ} \mathrm{mm} \mathrm{ha}^{-1} \mathrm{~h}^{-1} \mathrm{yr}^{-1}$. In general, Ticino is the region with the highest rainfall erosivity followed by elevated stations north of the Alps (e.g. Säntis, Adelboden; Fig. 4). Medium level erosivities are observed in the north-western part of Switzerland. The regions with the lowest rainfall erosivities are the Valais and Grisons (Fig. 4). An overview of the $R$-factor for each station is given in Table 1.

The average $R$-factor values found for Switzerland are similar to the ones published by Mikos et al. (2006) for an alpine region in Slovenia, which range from 1580 to $2700 \mathrm{MJ} \mathrm{mm} \mathrm{ha}^{-1} \mathrm{~h}^{-1} \mathrm{yr}^{-1}$ for different years of one station. However, the Ticino values are twice as high as the maximum value observed for the Slovenian station, which can be explained by higher annual precipitation means $(>1700 \mathrm{~mm}$ compared to $1370 \mathrm{~mm}$ in Slovenia) and by the strong influence of orographic rainfall in Ticino. Small erosivity values occur in the western and eastern parts of Switzerland, which is mainly due to a very low annual precipitation in combination with a high proportion of snowfall (identified by the temperature controlled snowfall threshold). The observed $R$ factor pattern corresponds well to the distribution of thunderstorms in Central Europe (van Delden, 2001). The frequency

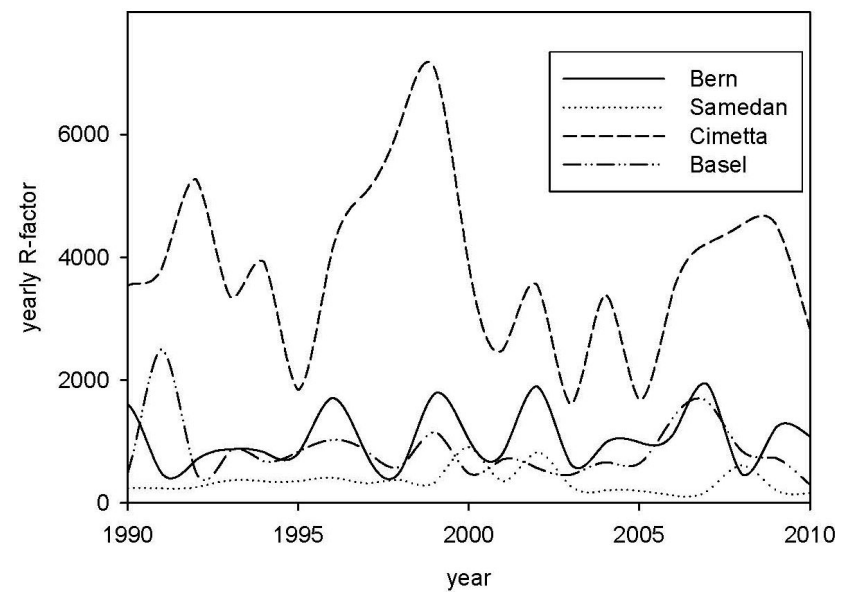

Fig. 6. Annual variability of $R$-factor for a station in Ticino (Cimetta), Grisons (Samedan) and two stations on the North side of the Alps (Bern, Basel).

of thunderstorms is reported to be high in the Jura Mountains, the Swiss plateau and the Po valley at the foot of the Alps. The latter is due to the source of warm moist air of the Mediterranean sea in combination with orographic uplift especially in the late summer season (van Delden, 2001). A relative minimum of thunderstorm frequency is reported for inner Alpine valleys (van Delden, 2001).

The relationship between the obtained erosivity map and the former map after the approximation equation of Rogler and Schwertmann (1981), which was adapted to Switzerland by Friedli et al. (2006) and Prasuhn et al. (2007) can be described by a linear equation $\left(R^{2}\right.$ adj. $=0.56$; Fig. 5 right). The original Rogler and Schwertmann equation that does not account for snowfall yields lower agreement $\left(R^{2}\right.$ adj. $=0.41$; Fig. 5 left). Even though the spatial pattern according to the adapted equation corresponds well, the rainfall erosivity is generally underestimated: average $R$-factor for all Swiss stations is $775 \mathrm{MJ} \mathrm{mm} \mathrm{ha}^{-1} \mathrm{~h}^{-1} \mathrm{yr}^{-1}$, which is $42 \%$ less than the $R$-factor determined using the original equation with the high temporal resolution data. The highest underestimation occurs for stations with high rainfall erosivity particularly in the Ticino (e.g. Locarno/Monti, Magadino/Cadenazzo, Stabio etc.). A slight overestimation is observed for stations in the West and Central Alps (e.g. Visp, Grimsel Hospitz, Altdorf and Sion). The equation of Rogler and Schwertmann (1981) was developed in the Bavarian Alps (Germany) and seems to be limitedly transferable to the Ticino and Valais region due to the strong influence of orographic effects.

\subsection{Temporal variability of rainfall erosivity}

Annual $R$-factor for the period 1989 to 2010 shows distinct inter-annual variability (Fig. 6). The coefficient of variation is large ( $45 \%$ for Bern, $36 \%$ for Cimetta), especially for the 
$200-439 m$ a.s.l.

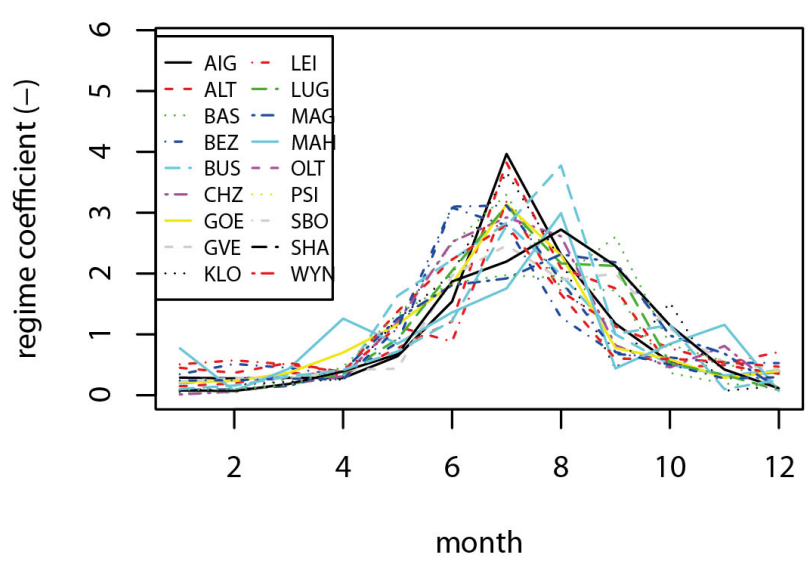

$630-1599 m$ a.s.l.

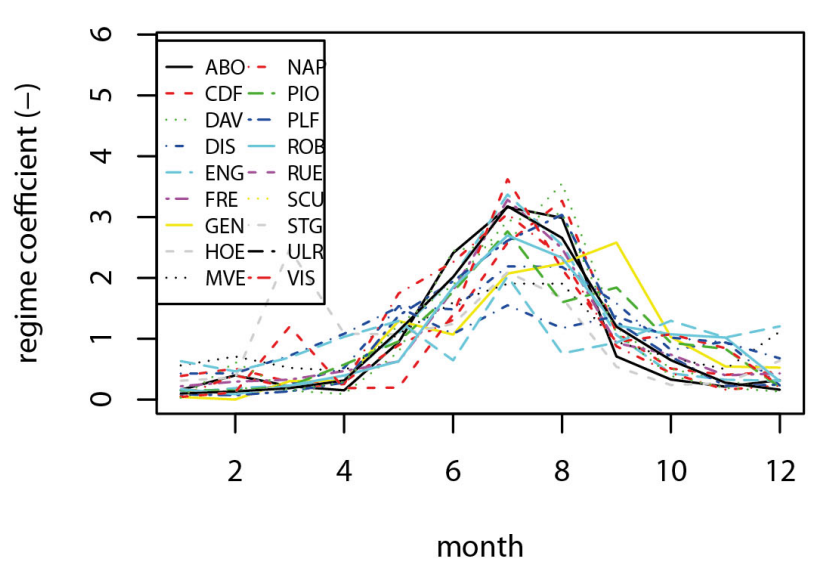

Fig. 7. Rainfall erosivity regimes grouped by elevation.

stations with lower $R$-factor (59\% for Samedan and $55 \%$ for Basel, respectively). This high variability is most likely the reason why seasonal Mann Kendall trend test of single stations (with data available for $22 \mathrm{yr}$ ) could not identify significant trends in rainfall erosivity. A high variability of $R$-factor is also observed for the yearly time-series that were tested with the Pettitt- Buishand-, SNHT- and Neumann ratio test. For none of the stations and tests the null hypothesis of homogenous data distribution could be rejected (at a $p=0.01$ level). Even no significant trend was found for a much longer time series of $105 \mathrm{yr}$ in Belgium (Verstraeten et al., 2006). To extract the intra-annual variability of rainfall erosivity, rainfall erosivity regimes were calculated. The regimes were grouped into altitudinal classes (Fig. 7). The rainfall erosivity is characterized by a strong seasonality with highest regime coefficients in the summer months (May to September) and lowest in the winter month (December to March). For elevated stations a more pronounced peak of rainfall erosivity in summer months is observed ( 3 to 5 times higher than
$440-629 m$ a.s.l.

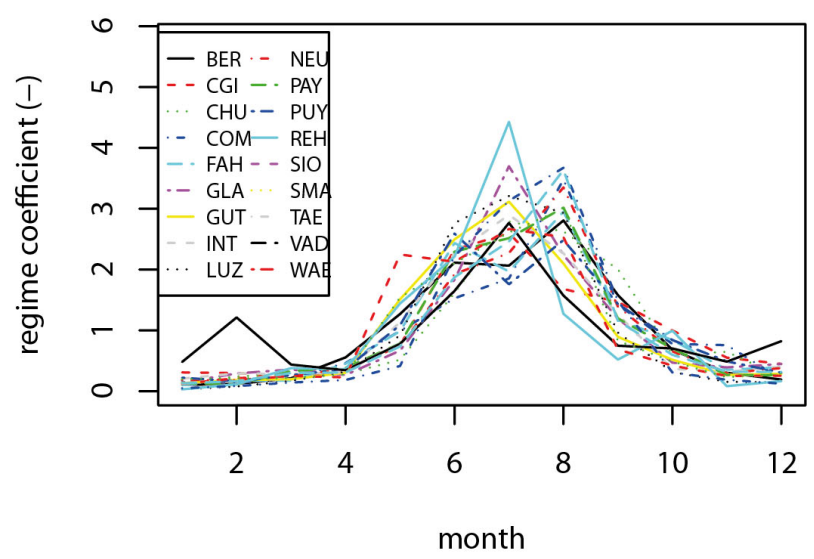

$1600-3285 m$ a.s.l.

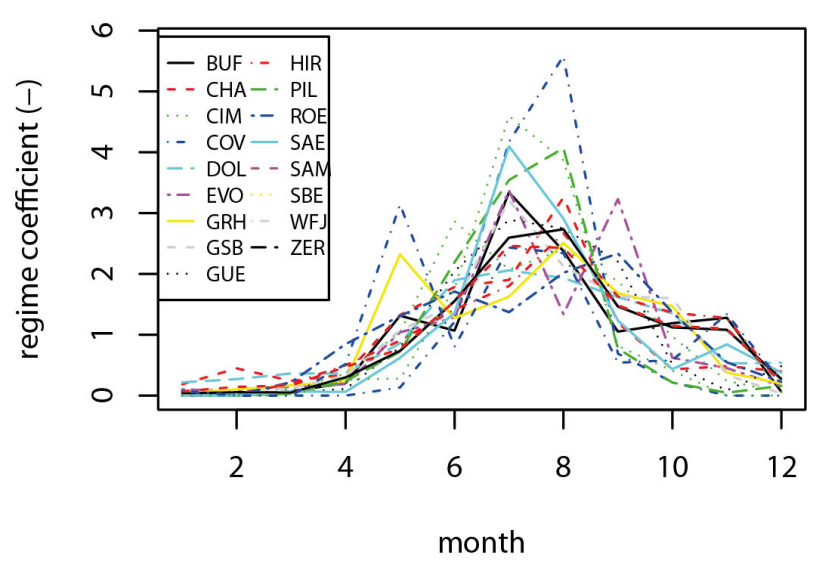

the average yearly rainfall erosivity), due to the long snowfall season e.g. station Corvatsch (3350 m a.s.l.). For most stations rainfall erosivity peaks in July or (particularly in the Jura and the northern Alps) in August. The erosivity regimes clearly highlight the importance of monthly rainfall erosivity maps for soil erosion risk assessment (Renard et al., 1997).

Mann-Kendall trend test for single months over the 22 investigated years identified a significant increasing trend of rainfall erosivity for May to October and a significant decreasing trend for February (Table 2). The observed increasing trend in the $R$-factor corresponds to climate change prognosis that predict reductions in average summer precipitation accompanied by an increase in high intensity precipitation events for many parts of Central Europe and the Alps (Christensen and Christensen, 2003; Schär et al., 2004; Frei et al., 2006). Further the trends are supported by an assessment of thunderstorms distribution for Europe, where the highest frequency was observed in the vicinity of the Alps for the season April to October (van Delden, 2001). 
Changes in rainfall erosivity cannot be directly linked to soil erosion risk because of the seasonal variability of vegetation cover. However, three out of the six month (May, September, October) with significant increasing trends can also be expected to have relatively sparse or instable vegetation cover, thus increasing soil erosion rates can be expected. Most cultivated areas (e.g. winter crop, corn, vegetable fields) as well as alpine grasslands will have low vegetation cover and water saturated conditions in May (Vandaele and Poesen, 1995; Le Bissonnais et al., 2002; Konz et al., 2010) and will be harvested/grazed in September/October (Favis-Mortlock and Boardman, 1995; Leek and Olsen, 2000; Helming et al., 2005) and will thus be susceptible to erosion during snow melt and/or heavy rain events.

For the winter season a decreasing erosivity trend for February was identified. Winter precipitation is predicted to increase by $10 \%$ for Switzerland (OcCC_ProClim, 2007). The duration of snow accumulation is expected to be reduced by up to 100 days (e.g. at the station Säntis) (Beniston, 2003) due to higher winter minimum temperatures. The combined effect of these developments is expected to increase soil erosion by runoff. However, do not necessarily result in an increase of high intensity events as defined by the (R)USLE $R$-factor.

\section{Conclusion and outlook}

The $R$-factor was successfully $\left(R^{2}\right.$ adj. $=0.80$ for the interpolation dataset and $R^{2}$ adj. $=0.76$ for the validation dataset) mapped for Switzerland using a regression-kriging approach. The availability of a rainfall erosivity map is a key issue not only for soil erosion and landslide risk assessment but also for agricultural management and soil conservation practices.

The application of a temperature threshold below $0{ }^{\circ} \mathrm{C}$ considering the low erosivity of snow fall improved the rainfall erosivity estimates for mountain areas. However, in mountain areas further research may be directed to quantify erosivity caused by snowmelt, snowgliding and avalanches, which is not yet accounted for in the $R$-factor.

The analysis of both the spatial and temporal patterns of rainfall erosivity yielded crucial new information for soil erosion assessment in Switzerland. First rainfall erosivity is on average $72 \%$ higher as expected from the former applied approximation equation proposed by Friedli et al. (2006) and particularly high rainfall erosivities were underestimated. The results obtained for the spatial and temporal distribution of the $R$-factor provides information on the relative importance of erosivity in different regions and also compared to other soil erosion risk factors. Second the monthly rainfall erosivity is significantly increasing in the months between May to October. These results imply that trends in time-series of single stations are likely, too. Further analysis of longer time-series is necessary to assess, which areas of Switzerland are affected by probably also opposed trends.
The added effect of high rainfall erosivity will most likely result in an increased soil erosion risk mainly in the month May, September and October for some parts of Switzerland with scarce vegetation cover. In order to implement soil conservation practices a detailed identification of the timing and location of erosion prone areas is necessary, which could be achieved by combining Swiss-wide monthly rainfall erosivity maps with the risk of soil being exposed and land use management information.

Acknowledgements. This study was funded by the Swiss Federal Office for the Environment in the framework of the Collaboration Agreement No. 31576. Special thanks to F. Carré for her introduction to regression-kriging.

Edited by: C. de Michele

\section{References}

Alexandersson, H.: A homogeneity test applied to precipitation data, J. Climatol., 6, 661-675, 1986.

Angulo-Martínez, M., López-Vicente, M., Vicente-Serrano, S. M., and Beguería, S.: Mapping rainfall erosivity at a regional scale: a comparison of interpolation methods in the Ebro Basin (NE Spain), Hydrol. Earth Syst. Sci., 13, 1907-1920, doi:10.5194/hess-13-1907-2009, 2009.

Arnoldus, H. M. J.: Methodology used to determine the maximum potential average annual soil loss due to sheet and rill erosion in Morocco, FAO Soils Bulletin, 34, 39-51, 1977.

Begert, M., Schlegel, T., and Kirchhofer, W.: Homogeneous Temperature and Precipitation Series of Switzerland from 1864 to 2000, Int. J. Climatol., 25, 65-800, 2005.

Beniston, M.: Climatic change in mountain regions: A review of possible impacts, Climatic Change, 59, 5-31, doi:10.1023/a:1024458411589, 2003.

Beniston, M.: Mountain weather and climate: A general overview and a focus on climatic change in the Alps, Hydrobiologica, 562, 3-16, 2006.

Bollinne, A., Laurant, A., and Boon, W.: L'érosivité des précipitations à Florennes. Révisioons de la carte des isohyètes et de la carte d'érosivité de la Belgique., Bulletin Société Géographique de Liège, 15, 77-99, 1979.

Brown, L. C. and Foster, G. R.: Storm erosivity using idealized intensity distributions, Transactions of the Asae, 30, 379-386, 1987.

Buishand, T. A.: Some methods for testing the homogeneity of rainfall records, J. Hydrol., 58, 11-27, doi:10.1016/00221694(82)90066-x, 1982.

Capolongo, D., Diodato, N., Mannaerts, C. M., Piccarreta, M., and Strobl, R. O.: Analyzing temporal changes in climate erosivity using a simplified rainfall erosivity model in Basilicata (southern Italy), J. Hydrol., 356, 119-130, doi:10.1016/j.jhydrol.2008.04.002, 2008.

Christensen, J. H. and Christensen, O. B.: Climate modelling: Severe summertime flooding in Europe, Nature, 421, 805-806, doi:10.1038/421805a, 2003.

Cressie, N.: Statistics for Spatial Data, edited by: Wiley, R. E., New York, 1993. 
Daly, C., Gibson, W. P., Taylor, G. H., Johnson, G. L., and Pasteris, P.: A knowledge-based approach to the statistical mapping of climate, Climate Research, 22, 99-113, doi:10.3354/cr022099, 2002

De Santos Loureiro, N. and De Azevedo Coutinho, M.: A new procedure to estimate the RUSLE EI30 index, based on monthly rainfall data and applied to the Algarve region, Portugal, J. Hydrol., 250, 12-18, 2001.

Diodato, N. and Bellocchi, G.: Estimating monthly (R)USLE climate input in a Mediterranean region using limited data, J. Hydrol., 345, 224-236, doi:10.1016/j.jhydrol.2007.08.008, 2007.

Diodato, N. and Bellocchi, G.: MedREM, a rainfall erosivity model for the Mediterranean region, J. Hydrol., 387, 119-127, doi:10.1016/j.jhydrol.2010.04.003, 2010.

Favis-Mortlock, D. and Boardman, J.: Nonlinear responses of soil-erosion to climate change-modeling study on the UK south-downs, CATENA, 25, 365-387, doi:10.1016/03418162(95)00018-n, 1995.

Frei, C., Scholl, R., Fukutome, S., Schmidli, J., and Vidale, P. L.: Future change of precipitation extremes in Europe: Intercomparison of scenarios from regional climate models, J. Geophys. Res.-Atmos., 111, D06105, doi:10.1029/2005jd005965, 2006.

Friedli, S.: Digitale Bodenerosionsgefährdungskarte der Schweiz im Hektarraster - unter besonderer Berücksichtigung des Ackerlandes, Diplomarbeit Geogr. Inst. Univ. Bern und Agroscope FAL Reckenholz, 110 pp., 2006.

Gonseth, Y., Wohlgemuth, T., Sansonnens, B., and Buttler, A.: Die biogeographischen Regionen der Schweiz. Erläuterungen und Einteilungsstandard Umwelt Materialien Nr. 137, Bundesamt für Umwelt, Wald und Landschaft Bern, 48, 2001.

Helming, K., Auzet, A. V., and Favis-Mortlock, D.: Soil erosion patterns: evolution, spatio-temporal dynamics and connectivity, Earth Surf. Proc. Land., 30, 131-132, doi:10.1002/esp.1179, 2005.

Hengl, T., Heuvelink, G. B. M., and Stein, A.: A generic framework for spatial prediction of soil variables based on regressionkriging, Geoderma, 120, 75-93, 2004.

Hirsch, R. M., Slack, J. R., and Smith, R. A.: Techniques of trend analysis for monthly water quality data., Water Resour. Res., 18, 107-121, 1982.

Hudson, N.: Cornell University Press. Soil Conservation, Ithaca, 1971

IPCC: Climate Change 2007: The physical science basis. Summary for policymakers., 661, 10th session of working group I of the IPCC, Paris, 2007.

Konz, N., Baenninger, D., Konz, M., Nearing, M., and Alewell, C.: Process identification of soil erosion in steep mountain regions, Hydrol. Earth Syst. Sci., 14, 675-686, doi:10.5194/hess-14-6752010, 2010.

Lal, R.: Soil erosion on alfisols in Western Nigeria. III-Effects of rainfall characteristics, Geoderma, 16, 389-401, 1976

Le Bissonnais, Y., Montier, C., Jamagne, M., Daroussin, J., and King, D.: Mapping erosion risk for cultivated soil in France, CATENA, 46, 207-220, doi:10.1016/s0341-8162(01)00167-9, 2002.

Leek, R. and Olsen, P.: Modelling climatic erosivity as a factor for soil erosion in Denmark: changes and temporal trends, Soil Use Manage., 16, 61-65, 2000.

Loureiro, N. D. and Coutinho, M. D.: A new procedure to esti- mate the RUSLE EI30 index, based on monthly rainfall data and applied to the Algarve region, Portugal, J. Hydrol., 250, 12-18, 2001.

Mann, H. B.: Nonparametric tests against trend, Econometrica, Econometrica,, 13, 245-259, 1945.

Meusburger, K. and Alewell, C.: Impacts of anthropogenic and environmental factors on the occurrence of shallow landslides in an alpine catchment (Urseren Valley, Switzerland), Nat. Hazards Earth Syst. Sci., 8, 509-520, doi:10.5194/nhess-8-509-2008, 2008.

Mikos, M., Jost, D., and Petkovsek, G.: Rainfall and runoff erosivity in the alpine climate of north Slovenia: a comparison of different estimation methods, Hydrol. Sci. J., 51, 115-126, 2006.

Mottet, A., Ladet, S., Coque, N., and Gibon, A.: Agricultural landuse change and its drivers in mountain landscapes: A case study in the Pyrenees, Agriculture, Ecosystems \& Environment, 114 296-310, 2006.

OcCC_ProClim: Climate Change and Switzerland 2050. Expected Impacts on Environment, Society and Economy, OcCC / ProClim, Bern, 168, 2007.

Panagos, P., Karydas, C. G., Gitas, I. Z., and Montanarella, L.: Monthly soil erosion monitoring based on remotely sensed biophysical parameters: a case study in Strymonas river basin towards a functional pan-European service, International Journal of Digital Earth, in press, doi:10.1080/17538947.2011.587897, 2011.

Pettitt, A. N.: A non-parametric approach to the change-point problem, Appl. Stat., 28, 13126-135135, doi:10.2307/2346729, 1979.

Prasuhn, V., Liniger, H., Hurni, H., and Friedli, S.: Map of soil erosion risk in Switzerland, Agrarforschung, 14, 120-127, 2007.

Renard, K. G. and Freimund, J. R.: Using monthly precipitation data to estimate the $R$-factor in the revised usle, J. Hydrol., 157, 287-306, doi:10.1016/0022-1694(94)90110-4, 1994.

Renard, K. G., Foster, G. R., and Weesies, G. A.: Predicting soil erosion by water; a guide to conservation planning with the revised universal soil loss equation (RUSLE), Agriculture Handbook No. 703, USDA-ARS, 404 pp., 1997.

Rogler, H. and Schwertmann, U.: Rainfall erosivity and isoerodent map of Bavaria, Zeitschrift für Kulturtechnik und Flurbereinigung, 22, 99-112, 1981 .

Santosa, P. B., Mitani, Y., and Ikemi, H.: Estimation of RUSLE EI 30 based on 10 min interval rainfall data and GIS-based development of rainfall erosivity maps for Hitotsuse basin in Kyushu Japan, 18th International Conference on Geoinformatics, 2010, INSPEC:11532406, 2010.

Schär, C., Vidale, P. L., Lüthi, D., Frei, C., Häberli, C., Liniger, M., and Appenzeller, C.: The role of increasing temperature variability in European summer heat waves, Nature, 427, 332-336, 2004.

Schüpp, M.: Objective weather forecasts using statistical aids in Alps, Rivista Italiana Di Geofisica E Scienze Affini, 1, 32-36, 1975.

Schwarb, M.: The alpine precipitation climate. The alpine precipitation evaluation of a high-resolution analysis scheme using comprehensive rain-gauge data, Doctoral and Habilitation Theses. Diss. ETHNo, 13911, Swiss Federal Institue of Technology, Zürich 2000.

Strauss, P. and Blum, W. E. H.: $R$-factoren Österreichs und Bayerns 
- ein Vergleich, Mitteilungen der Deutschen Bodenkundlichen Gesellschaft, 74, 137-140, 1994.

Tasser, E. and Tappeiner, U.: Impact of land use changes on mountain vegetation, Appl. Veg. Sci., 5, 173-184, 2002.

van Delden, A.: The synoptic setting of thunderstorms in western Europe, Atmos. Res., 56, 89-110, doi:10.1016/s01698095(00)00092-2, 2001.

Vandaele, K. and Poesen, J.: Spatial and temporal patterns of soil-erosion rates in an agricultural catchment, Central Belgium, CATENA, 25, 213-226, doi:10.1016/0341-8162(95)00011-g, 1995.

Verstraeten, G., Poesen, J., Demaree, G., and Salles, C.: Long-term (105 years) variability in rain erosivity as derived from 10-min rainfall depth data for Ukkel (Brussels, Belgium): Implications for assessing soil erosion rates, J. Geophys. Res.-Atmos., 111, D2210910, doi:10.1029/2006jd007169, 2006.
Von Neumann, J.: A further remark concerning the distribution of the ratio of the mean square successive difference to the variance, Ann. Math. Stat., 13, 86-88, doi:10.1214/aoms/1177731645, 1942.

Weisse, A. K. and Bois, P.: A comparison of methods for mapping statistical characteristics of heavy rainfall in the French Alps: the use of daily information, Hydrol. Sci. J., 47, 739-752, doi:10.1080/02626660209492977, 2002.

Wischmeier, W. H. and Smith, D. D.: Predicting Rainfall Erosion Losses - A Guide to Conservation Planning. Agric. Handbook No. 537, Washington D.C., 58, 1978. 